\title{
Failure to Unfold or Unwrap
}

National Cancer Institute

\section{Source}

National Cancer Institute. Failure to Unfold or Unwrap. NCI Thesaurus. Code C62949.

Problem associated with the comprising materials' deformation in that device fails to open its wrapping or open/extend in a certain manner i.e. balloon or lens. 